\title{
Antioxidant Activity And Phenolic Compounds Contents Of Spider Flower (Cleome Arabica Ssp.Arabica), A Well Acclimated Species In The Algerian Desert Areas
}

\begin{abstract}
Madi Aicha, (Assistant teacher class A)
Pharmacology and toxicology laboratory, Veterinary Institut. Faculty of natural science, Mentouri brothers1. Constantine university, Algeria

Zaghed Nadia, (Assistant teacher class A)

Pharmacology and toxicology laboratory, Veterinary Institut. Faculty of natural science, Mentouri brothers 1. Constantine university, Algeria

Halmi Sihem, (Doctor)

Pharmacology and toxicology laboratory, Veterinary Institut. Faculty of natural science, Mentouri brothers 1. Constantine university, Algeria
\end{abstract}

Belkhiri Abdelmalik, (Professor)

Pharmacology and toxicology laboratory, Veterinary Institut. Faculty of medecine, University Constantine 3, Algeria

doi: 10.19044/esj.2017.v13n12p102 URL:http://dx.doi.org/10.19044/esj.2017.v13n12p102

Abstract

A detailed study was performed on the antioxidant activity of the alcoholic extract of different plant parts of Cleome Arabica ssp. arabica (CAA) in relation with their total phenolic, flavonoid and proanthocyanidins contents in order to find possible sources for future novel antioxidants in food and pharmaceutical formulations.

The total yield, total phenolic (TP), total flavonoids (TF) and total proanthocyanidins (TPA) contents of all the fractions were also determined. Cleome Arabica ssp. arabica was also subjected to preliminary phytochemical screening test for various constituents.

The total phenolic contents (TPC) of three parts (Leaves, seeds and roots) was 78,56 $\pm 0,01 \mathrm{mg} \mathrm{GAEq} / \mathrm{g}$ extract, while total flavonoid contents (TFC) of the same parts was $19,57 \pm 0,01 \mathrm{mg} \mathrm{REq} / \mathrm{g}$ extract, and total proanthocyanidins (TPA) was 17,41 $\pm 0,01 \mathrm{mg}$ CYEq/ g of extract. Leaves extract was found significantly higher as compared to other parts extracts.

Phytochemical screening of leaves, seeds and roots extracts revealed the presence of alkaloids, coumarins, flavonoids, saponins, tannins and terpenoids. 
The antioxidant capacity of extracts was determined by three methods DPPH, FRAP, and phosphomolybdenum. The obtained results showed that leaves extract has the highest antioxidant capacity with low value of IC50 for DPPH and FRAP and the highest quantity of antioxydants compounds in phosphomolybdenum assay, followed by seeds extract and finally roots extract.

Keywords: Cleome Arabica, phenolic compounds content; DPPH, FRAP, phosphomolybdenum assay

\section{Introduction}

There is evidence to support the involvement of reactive oxygen species (ROS) in several human disorders such as diabetes, cancer, cardiovascular and neurodegenerative diseases (Schwartsburd, 2003). Antioxidants are compounds that inhibit or alter the oxidation process of biomolecules, such as proteins, lipids, carbohydrates and DNA and so reduce their negative impact on health (Aruoma et al, 1995). The antioxidant activity of a compound is often associated with their redox proprieties, which allow them to act as reducing agents (Diouf et al, 2009; Siddhuraju, 2002).

In recent years, rising demands are recorded for natural antioxidants from pharmaceuticals, food and beverages sector, feed additive, cosmetic industry, etc (Carocho \& Ferreira, 2013), and this trend is expected to continue in the years to come. Moreover, attention has been directed towards the prospection of plant extracts and the evaluation of phytochemicals for their antioxidant potential.

Phenolic compounds constitute one of the major groups of phytochemicals acting as free radical scavengers and antioxidants (Stevanovic, 2009).

It is well established that plant chemical composition is affected by genetic (species) and environmental factors (Seigler, 2002). Prospecting plants from particular stressed ecosystems can be an interesting strategy for the discovery of new molecule structures with a powerful antioxidant activity. Plants from desert formations, like dayas and chotts (saline lakes), found in the great Algerian Sahara might be of potential sources to prospect.

Cleome arabica L. [Capparidaceae)], known as spider flower, is a common well acclimated species in the desert areas of southern Algeria. Entire plant has an unpleasant odor and is a little grazed by animals. The leaves are described as having hallucinogenic effects and are used in traditional medicine for treatment of scabies, inflammation and as a sedative for abdominal and rheumatic pains (Baba Aissa, 2011; Tsichritzis et al, 1993; Ahmad et al, 1990; Boulos, 1983). Experimental evaluations of $C$. Arabica have reported an anti-diabetic activity in rats, as well as anti- 
inflammatory, analgesic, antipyretic and insecticidal properties (Ladhari et al, 2013; El-Mougy et al, 1991). Previous phytochemical investigations of the leaves have revealed the presence of dammarane triterpenes, including cleocarpanol and cabraleahydroxy lactone (Harraz et al, 1995; Tsichritzis et al 1993; Jente et al 1990; Cascon \& Brown, 1972) and high content of glucosylated flavonols (Bouriche \& Arnhold 2010).

Flavonoids and phenolic acids, in free or complex forms, represent the main classes of natural antioxidant compounds in nature (Carocho \& Ferreira, 2013; Krishnaiah et al 2011; Perron \& Brumaghim 2009; Einbond, 2004; Soares, 2002). Interest in phenolic compounds has increased considerably and studies aiming to define the structural features of phenolic compounds associated to oxidation inhibitory effect are intensely pursued (Oomah \& Mazza, 1996; Foti et al, 1996; Nieto et al, 1993; Das \& Pereira, 1990).

The present study of $C$. Arabica, focuses on the characterization of phenolic compounds content of the different parts (leaves, seeds and roots), and their antioxidant activity with a view to the exploitation of this Algerian desert species, as a local source of natural antioxidants.

\section{Experimental Section \\ Herbal material}

Plant parts were collected in April 2011 nearby Biskra (400 km south east from Algiers). Specimen of flowering plant was formally identified by Pr. Hocine Laouer (LVRBN,Ferhat Abbas University,Setif), and voucher specimen $\mathrm{n}^{\circ} \mathrm{CA} 1101$ was deposed for further reference at the herbarium of botanical department, pharmacy school (University Constantine 3).

\section{Extraction method}

Different parts (leaf, seed, and root) of the dried plant were separately grounded and immediately extracted with hydro-alcoholic solution at $70 \%$ of ethanol $(1 / 50, \mathrm{~m} / \mathrm{v}$ dried material). Extraction was carried out for 2 hours using ultrasonic bath at low temperature. After filtration and alcohol removing at moderate temperature $\left(<45^{\circ}\right)$, aqueous extracts were defatted with $2 \times 30 \mathrm{ml}$ of petroleum ether $\left(40-60^{\circ} \mathrm{C}\right)$ as previously recommended (Laghari et al , 2013). The remaining defatted aqueous extracts were immediately lyophilized and conserved at low temperature $\left(<6^{\circ}\right)$ until required for analysis.

\section{Phytochemical screening tests}

Phytochemical screening was described by Harbone (1998). Preparation of stock solution and different analysis were made following protocol of Amzad et al (2013); 1g of the lyophylised extract of leaves, 
seeds and roots were dissolved in $100 \mathrm{ml}$ of distilled water to obtain a stock solution.

\section{Test of alkaloids}

The stock crude extract $(5 \mathrm{ml})$ was added hydrochloric acid $(2 \mathrm{ml})$. One milliliter of Dragendroff's reagent was added to this acidic medium. An orange or red precipitation immediately produced that indicates the presence of alkaloids.

\section{Test of tannins}

The stock solution $(3 \mathrm{ml})$ was taken in a test tube and diluted with chloroform and added acetic anhydride $(1 \mathrm{ml})$. Finally, sulphuric acid $(1 \mathrm{ml})$ was added carefully by the side of test tube to the solution. A green colour was formed which showed the presence of tannins.

\section{Test of saponin}

The stock solution $(1 \mathrm{ml})$ was taken in a test tube and diluted with 20 $\mathrm{mL}$ of distilled water. It was shaken by hand for $15 \mathrm{~min}$. A foam layer was obtained on the top of the test tube. This foam layer indicated the presence of saponins.

\section{Test of steroids}

The crude plant extract ( $1 \mathrm{mg}$ ) was taken in a test tube and dissolved with chloroform $(10 \mathrm{ml})$, then added equal volume of concentrated sulphuric acid to the test tube by sides. The upper layer in the test tube was turns into red and sulphuric acid layer showed yellow with green fluorescence. It showed the presence of steroids.

\section{Test of triterpenoids}

The dry crude plant extract $(5 \mathrm{mg})$ was dissolved in chloroform (2 $\mathrm{ml})$ and then acetic anhydride $(1 \mathrm{ml})$ was added to it. Concentrated sulphuric acid $(1 \mathrm{ml})$ was added to the solution. Formation of reddish violet colour shows the presence of triterpenoids.

\section{Test of flavonoids}

The crude stock extract solution $(1 \mathrm{ml})$ and a few drops of dilute sodium hydroxide were added. An intense yellow colour was appearance in the plant crude extract, which become colourless on addition of a few drops of dilute acid indicates the presence of flavonoids (Dawood \& Amzad, 2011). 


\section{Test of coumarines}

$5 \mathrm{ml}$ of extract was added to $(0.5 \mathrm{ml})$ of $25 \% \mathrm{NH}_{4} \mathrm{OH}$. Observation of fluorescence under a UV lamp at $366 \mathrm{~nm}$ of intense fluorescence in the tube after adding ammonia indicates the presence of coumarin (Rizk, 1982).

\section{Total phenolic compounds content}

The total phenolic compounds content was determined by Folin Ciocalteu method, modified as previously reported by Amzad et al (2013). Briefly, crude extracts from different plant parts were dissolved in distilled water $(1 \mathrm{mg} / \mathrm{ml})$, and $1 \mathrm{ml}$ of each aqueous extract solution was added to 1.5 $\mathrm{ml}$ of Folin Ciocalteu solution (10\%) reagent. After 5mn of dark incubation, $1.5 \mathrm{ml}$ of $5 \%$ sodium carbonate $\left(\mathrm{Na}_{2} \mathrm{CO}_{3}\right)$ was added. The mixture was allowed to stand in the dark for 2 hours. All tests were performed in triplicate. The absorbance was measured by using spectrophotometer UVvisible at $750 \mathrm{~nm}$ against blank. The total phenolic content was calculated from the calibration curve, and the results were expressed as mg of gallic acid equivalent per $\mathrm{g}$ of extract. Gallic acid calibration curve was prepared by following the same procedure as above $\left(\mathrm{Y}=10.14 \mathrm{X}, \mathrm{R}^{2}=0.94\right)$.

\section{Total flavonoids content}

The total flavonoid content of crude extract was determined by the aluminium chloride colorimetric method (Karabegovic et al, 2011), modified as described before by Djeridane et al (2006). Crude extracts from different plant parts were dissolved in distilled water $(0.1 \mathrm{mg} / \mathrm{ml})$, and $2 \mathrm{ml}$ of each aqueous extract solution was added to $2 \mathrm{ml}$ of aluminium chloride solution $\left(\mathrm{AlCl}_{3} 2 \%\right)$. The mixture was allowed to stand for $15 \mathrm{~min}$, and absorbance was measured at $430 \mathrm{~nm}$. The total flavonoid content was calculated from a calibration curve, and the result was expressed as mg of rutin equivalent per $\mathrm{g}$ of extract. All tests were performed in triplicate. Rutin calibration curve was prepared by following the same procedure as above, and the amount of flavonoids was expressed in $\mathrm{mg}$ equivalent of rutin per $\mathrm{g}$ of extract $\left(\mathrm{Y}=20.25 \mathrm{X}, \mathrm{R}^{2}=0.99\right)$

\section{Proanthocyanidins content}

The assay was done according to Vermirris \& Nicholson (2006) method. Briefly, crude extracts from different plant parts were dissolved in distilled water $(1 \mathrm{mg} / \mathrm{ml})$, and $250 \mu 1$ of each aqueous extract solution was added to $2.5 \mathrm{ml}$ of acidic solution of ferrous sulphate. After incubation at $95^{\circ} \mathrm{C}$ for $50 \mathrm{~min}$, the absorbance was measured at $530 \mathrm{~nm}$ against blank. The condensed tannins were expressed as $\mathrm{mg}$ of cyanidin equivalent per $\mathrm{g}$ of plant extract. All tests were performed in triplicate. 
The amount of condensed tannins was calculated by using the following formula: $\quad$ Tannins condensed content $=\mathrm{A} 550 * \mathrm{DF} * \mathrm{MW} / \boldsymbol{C}^{*} 1$. where :

DF : dilution factor.

MW :cyanidin molecular weight $(288 \mathrm{~g} / \mathrm{mol})$.

$\sum$ : molecular extinction coefficient $(347001 / \mathrm{mol} / \mathrm{cm})$.

\section{Antioxidant activities}

Antioxidant activity was measured using three testing models: phosphomolybdenum, DPPH and reducing power assays (FRAP).

\section{Phosphomolybdenum assay}

The phosphomolybdenum method is based on the reduction of molybdenum by antioxidants which results in a formation of green molybdenum complex (Sudha et al, 2011). Briefly, crude extracts from different plant parts were dissolved in distilled water $(1 \mathrm{mg} / \mathrm{ml})$, and $0.1 \mathrm{ml}$ of each aqueous extract solution was added to $1 \mathrm{ml}$ of a solution containing $0.6 \mathrm{M}$ sulfuric acid, $28 \mathrm{nM}$ sodium phosphate and $4 \mathrm{nM}$ ammonium molybdate. All test tubes were capped in dark at $90^{\circ} \mathrm{C}$ for $90 \mathrm{~min}$. The absorbance was measured at $695 \mathrm{~nm}$. Ascorbic acid was used as a reference antioxidant and the results were expressed in $\mathrm{mg}$ gallic acid equivalent per gram of extract $\left(\mathrm{Y}=4.28 \mathrm{X}, \mathrm{R}^{2}=0.92\right)$.

\section{1,1-Diphenyl-2-picryl-hydrazyl assay (DPPH)}

The antioxidant activity of the extract was determined by the 1,1diphenyl-2-picryl-hydrazyl (DPPH) assay as described before (Braho et al , 2013), modified as follows. Briefly, crude extracts from different plant parts extracts were prepared in methanol $(1 \mathrm{mg} / \mathrm{ml})$. A serial dilution was performed from the stock alcoholic solution to obtain a range of concentrations $[1 \mathrm{mg} / \mathrm{ml}-0.1 \mathrm{mg} / \mathrm{ml}]$. A volume $(2 \mathrm{ml})$ of each dilution was mixed with $2 \mathrm{ml}$ of DPPH alcoholic solution $(0.0394 \mathrm{~g} / \mathrm{l})$. After incubation in the dark at room temperature for $30 \mathrm{~min}$, the absorbance of the mixture was measured at $517 \mathrm{~nm}$. Ascorbic acid and rutin were used as positive controls. All tests were performed in triplicate.

The ability of the sample to scavenge DPPH radical was determined from the formula:

Scavenging activity $\%=[($ A control - A sample $) / A$ control $] * 100$

The half maximal scavenging activity concentration (IC50) of free radical is deduced from result. Low IC 50 value indicates power capacity of extract to neutralize the free radical DPPH. 


\section{Ferric reducing power assay (FRAP)}

The reducing power of extract of different plant parts was determined according to a previously described protocol (Amarowicz et al, 2010). In practice, crude extracts from different plant parts were dissolved in deionized water $(1 \mathrm{mg} / \mathrm{ml})$, and $1 \mathrm{ml}$ of each aqueous extract solution wasadded to 2.5 $\mathrm{ml}$ of phosphate buffer $(\mathrm{pH} 6.6)$ and $2 \mathrm{ml}$ of potassium ferricyanide (1\%). The mixture was incubated at $50^{\circ} \mathrm{C}$ for a period of $20 \mathrm{~min}$, then $2,5 \mathrm{ml}$ of trichloroacetic acid solution (10\%) was added to the mixture and centrifuged for $10 \mathrm{~min}$ at $3000 \mathrm{tr} / \mathrm{min}$. The upper layer $(2.5 \mathrm{ml})$ was mixed with $2.5 \mathrm{ml}$ of deionized water and $0.5 \mathrm{ml}$ of ferric chloride solution $(0.1 \%)$. The absorbance was measured at $700 \mathrm{~nm}$. Higher absorbance indicates a strong extract reducing power. All tests were run in triplicate, and IC 50 was calculated from absorbance graph.

\section{Statistical Analysis}

The results are expressed as the mean of three measurements \pm standard deviation. The ANOVA variance analysis was applied to compare the means followed by the Tukey test. The statistical significance threshold was set at $\mathrm{p}<0.05$. Descriptive statistical analysis was performed using Microsoft Excel.

\section{Results \& Discussion}

Extraction yield and phenolic compounds contents in different parts

The soluble solids extraction yields and phenolic compounds contents obtained from different parts of $C$. arabica are given in Table 1.

Table 1 : Estimation of yield extraction, TP, TF, and PA.

\begin{tabular}{|c|c|c|c|c|}
\hline Content & $\mathrm{EM}^{\infty}(\mathrm{g} / 100 \mathrm{~g})$ & $\mathrm{TP}^{\mathrm{a},{ }^{*}}(\mathrm{mg} / \mathrm{g})$ & $\mathrm{TF}^{\mathrm{b}, *}(\mathrm{mg} / \mathrm{g})$ & $\mathrm{PA}^{\mathrm{c},{ }^{*}}(\mathrm{mg} / \mathrm{g})$ \\
\hline Leaf & $13,33 \pm 1,33^{* * *}$ & $35.17 \pm 0.01 * * *$ & $11.35 \pm 0.01 * * *$ & $5.15 \pm 0.01 * * *$ \\
\hline Seed & $12,86 \pm 0,19 * * *$ & $28.86 \pm 0.01 * * *$ & $5.31 \pm 0.01 * * *$ & $7.77 \pm 0.02 * * *$ \\
\hline Root & $5,53 \pm 0,15^{* * *}$ & $14.53 \pm 0,01 * * *$ & $2.91 \pm 0.01 * * *$ & $4.49 \pm 0.01 * * *$ \\
\hline
\end{tabular}

${ }^{\mathrm{a}}$ expressed as $\mathrm{mg}$ of gallic acid equivalent (GAeq) per $1 \mathrm{~g}$ of extract. ${ }^{\mathrm{b}}$ expressed as mg rutin equivalent (Req) per $1 \mathrm{~g}$ of extract. ${ }^{\mathrm{c}}$ expressed as $\mathrm{mg}$ of cyanidin equivalent (CYeq) per $1 \mathrm{~g}$ of extract. ${ }^{\text {o }}$ Extractible matter yield expressed as $\mathrm{g}$ of solid soluble extract per $100 \mathrm{~g}$ of dry matter. * each value is the average of three analyses \pm standard deviation, test tukey(HSD), 95\%

The alcoholic-extractible matters (EM) in the examined parts of $C$. Arabica ranged from 5,53 to $13,33 \mathrm{~g} / 100 \mathrm{~g}$. Leaf's extract showed the highest yields of EM $(13,33 \mathrm{~g} / 100 \mathrm{~g})$, compared to the root $(5,53 \mathrm{~g} / 100 \mathrm{~g})$ and the seed $(12,867 \mathrm{~g} / 100 \mathrm{~g})$. 
Comparative estimation of the three main phenolic fractions [Total phenolic (TP), total flavonoid (TF) and proanthocyanidins (PA)] in the different parts of $C$. Arabica revealed that the highest TP $(35.17 \pm 0.01 \mathrm{mg} / \mathrm{g}$ GAeq/g extract) and TF $(11.35 \pm 0.01 \mathrm{mg}$ Req $/ \mathrm{g}$ extract) contents were observed in the leaf, with a relatively moderate concentration of PA $(5.15 \pm$ $0.01 \mathrm{mg} \mathrm{CYeq} / \mathrm{g}$ extract). However, the seed showed the greatest PA content (7.77 $\pm 0.02 \mathrm{mg} \mathrm{CYeq} / \mathrm{g}$ extract), compared to the other examined parts. Moreover, root's extract contains considerably smaller concentrations of TP (14.53 $\pm 0.01 \mathrm{mg} / \mathrm{g} \mathrm{GAeq} / \mathrm{g}$ extract), TF $(2.91 \pm 0.01 \mathrm{mg}$ Req $/ \mathrm{g}$ extract $)$ and PA (4.49 $\pm 0.01 \mathrm{mg} \mathrm{CYeq} / \mathrm{g}$ extract). Statistical analysis results presented a very high significant difference between all value of leaves, seeds and roots.

\section{Phytochemical screening}

Parallel to the estimation of phenolic compounds contents, a phytochemical screening of $C$. Arabica was carried on the different parts (table 2), and revealed the presence of flavonoids, steroids, alkaloids, terpanoids. These results are confirmed by other works; Ismail et al , 2005 and Touil et al , 1998 have identified many glycosids and rhamnosyl flavonoids in this plant, djeridan et al , 2010 confirmed the presence of steroids, Takhi et al , 2011 proved the presence of alkaloids in Cleome arabica extract. Harraz et al, 1995 have reported that Cleome amblyocarpa which it's a subspecies of Cleome arabica has terpenoids in its composition, and Sharaf et al, 1997 confirmed presence of glycosilated flavonoids in the same species.

Table 2 : phytochemical screening of Leaves, seeds and roots.

\begin{tabular}{|c|c|c|c|}
\hline Molecules groups & Leaves & Seeds & Roots \\
\hline Alkaloïds & +++ & - & - \\
\hline Tannins & +++ & ++ & + \\
\hline Saponins & +++ & + & + \\
\hline Stéroïds & +++ & ++ & + \\
\hline Triterpens & +++ & ++ & + \\
\hline Flavonoïds & +++ & ++ & + \\
\hline Coumarins & +++ & ++ & + \\
\hline
\end{tabular}

+ : presence $(+++$ intense color, ++ medium color,+ light color $)$

- : Absence

\section{Antioxidant activity and reducing power}

Antioxidant activity (phosphomolybdenum and DPPH) and reducing power (FRAP) were measured for the alcoholic extracts of the different parts of spider flower (Cleome arabica L.), and results are illustrated as follows. 


\section{DPPH assay}

DPPH scavenging activity of investigated plant parts (Leaf, seed, root) extracts are presented in terms of percentage inhibition (\%) and IC50 values $(\mathrm{mg} / \mathrm{ml})$ (Figure 2).

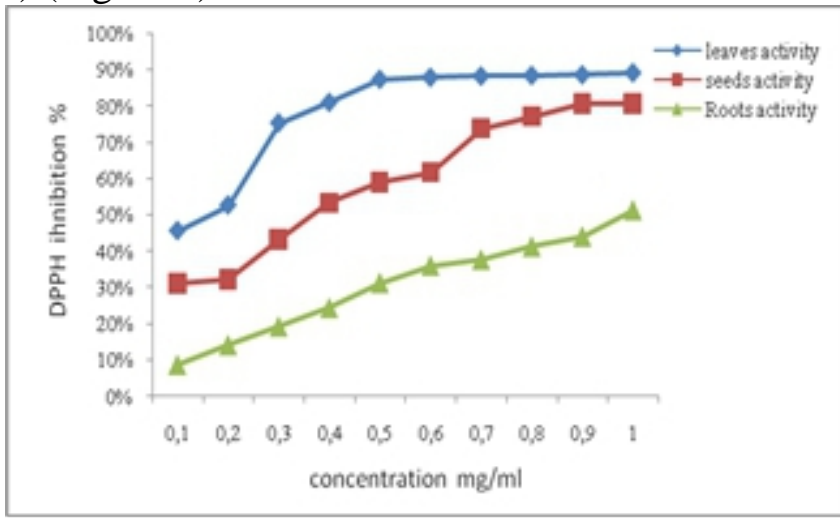

Figure 2 : Antioxidant (DPPH scavenging) activity of investigated plant parts extracts, presented as percentage of DPPH radicals inhibition and IC50 values $(\mathrm{mg} / \mathrm{ml})$.

Parallel to this examination, the IC50 values for two standard compounds, rutin and ascorbic acid, were obtained and compared to the obtained values of plant extracts. The DPPH scavenging activity of investigated plant parts (Leaf, seed, root) extracts showed different values that ranged from $51.2 \%$ to $89.0 \%$. The largest capacity to neutralize DPPH radicals was found for leaf's alcoholic extract, which neutralized $50 \%$ of free radicals at the concentration of $0.09 \mathrm{mg} / \mathrm{ml} * * *$. A moderate activity was found for seed's extract (IC50=0.46 $\mathrm{mg} / \mathrm{ml}^{* * *}$ ), and the capacity to inhibit DPPH radicals was determined for root's extract (IC50 $=0.97 \mathrm{mg} / \mathrm{ml} * * *)$. In comparison to IC50 values of rutin (IC50 $=0.01 \mathrm{mg} / \mathrm{ml}$ ) and ascorbic (IC50= $0.02 \mathrm{mg} / \mathrm{g}$ ) acid, leaf's alcoholic extract from C. Arabica (IC50=0.09mg/ml) manifested the strongest capacity for neutralization of DPPH radicals. DPPH IC50 values of leaves, seeds and roots extract are significantly different from ascorbic acid and rutin values.

\section{Phosphomolybdenum assay}

Results of the total antioxidant capacity obtained through the phosphomolybdenum assay for each plant parts (leaf, seed, root) extract are presented in table $3\left(\mathrm{Y}=4.28 \mathrm{X}, \mathrm{R}^{2}=0.92\right)$.

Table 3: Determination content of phosphomolybdenum essay.

\begin{tabular}{|c|c|c|c|}
\hline CONTENT & Leaves extract & Seeds extract & Roots extract \\
\hline Phosphomolybdenum assay mg GAE/g & $14,00 \pm$ & $12,05 \pm$ & $10,03 \pm$ \\
extract & $0,01 * * *$ & $0,004 * * *$ & $0,003^{* * *}$ \\
\hline
\end{tabular}


Overall, the leaf's extract exhibited a much better antioxidant effect than those of seed $(12.05 \pm 0.01 \mathrm{mg} \mathrm{GAeq} / \mathrm{g})$ and root $(10.03 \pm 0.01 \mathrm{mg}$ GAeq/g), as demonstrated by the highest value of gallic acid equivalent $(14.00 \pm 0.01 \mathrm{mg} \mathrm{GAeq} / \mathrm{g})$. These results are consistent with the low antiradical effects recorded for the seed and the root extracts, when compared to that of the leaf, as determined by the DPPH assay. The phospshomolybdenum values of leaves, seeds and roots extracts present a very high significant difference.

\section{FRAP assay}

The results (Figure 4) showed that FRAP values were higher for $C$. Arabica leaf's extract compared to other plant parts extracts (seed, root), and this overall the ferrous salts concentration range.

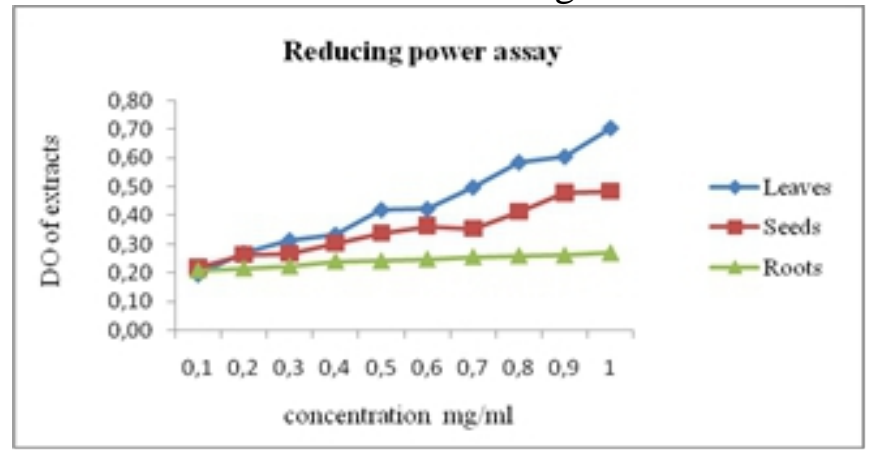

Figure 4 : FRAP values in C. arabica (leaf, seed, root) presented as absorbance and IC50 values $(\mathrm{mg} / \mathrm{ml})$.

Leaf's extract has a FRAP value of $0,67 \pm 0,001 * * * \mathrm{mg} / \mathrm{ml}$ followed by seed's extract with $1,07 \pm 0,006^{* * *} \mathrm{mg} / \mathrm{ml}$ and root's extract with $4,47 \pm$ $0,072 * * * \mathrm{mg} / \mathrm{ml}$. These results are consistent with previous evaluation of antioxidant activity made by DPPH and phosphomolybdenum assays. FRAP value of leaves, seeds and roots extracts present a very high significant difference. However, the comparaison of our obtained results values with those obtained by others authors is not possible, due to difference of assays, diffrence of reactifs, the expression way of results and also simple treated, although, the antioxydant effect of leaves and arial part of Cleome arabica was proved by Djeridanne et al 2010, Selloum et al 1997, Tigrin et al 2013 which used different antioxydant tests.

Correlations between the Content in content of Polyphenols and Antioxidant Capacities :

In this study, three parts of Cleome arabica are investigated to evaluate their potential antioxydant activities by three methods DPPH, FRAP, and phosphomolybdenum essay ; the results show an appreciate level of this activity. Polyphenols and flavonoids were quantified, and many 
research interest to study these two groups of metabolites and their relationship with antioxydant properties. So, to enrich our results, the correlation between total phenols, flavonoids content and different antioxydant activities was evaluated. (figure 5, 6 and table 4).

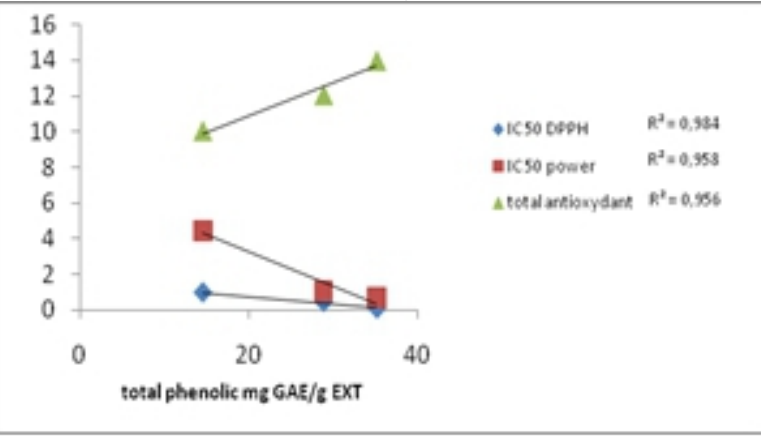

Figure 5 : Correlation curves between total phenolic content and antioxydant activities.

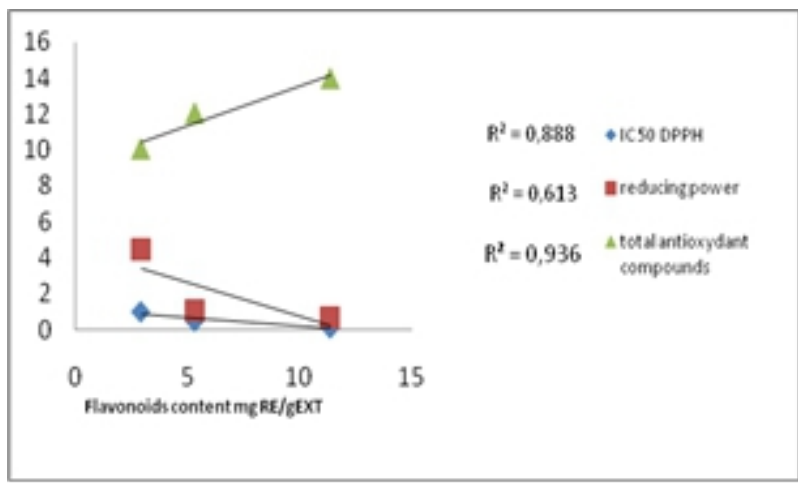

Figure 6 : Correlation curves between flavonoids content and antioxydant activities.

The obtained values of correlation coefficients are presented in table 4.

Table 4: Correlation coefficients between total phenolic, flavonoids content and antioxydant activities.

\begin{tabular}{|c|c|c|c|}
\hline $\mathrm{R}$ & DPPH & Reducing power & Total antioxydant compound \\
\hline Total Phenolic & $-0,99$ & $-0,98$ & 0,98 \\
Flavonoids & $-0,94$ & $-0,78$ & 0,97 \\
\hline
\end{tabular}

The results show a good correlation between the DPPH scavenging capacity of extracts and their content of total phenolic $(r=-0,99)$ and also flavonoids $(r=-0,94)$. This means that the scavenger of DPPH free radical my be attributed at their ability to provide hydrogen to this radical in order to stabilize it (Kasangana et al , 2015). This stabilization is visualized by the color change from purple to yellow, the degree of colour change is proportional to the concentration and potency of the antioxydants (Naima et al 2012). 
Furthermore, as show in table 4, there is a significant correlation found between the power reducing assay (FRAP) and content of total phenolic compound with $\mathrm{r}=-0,98$, and more less correlation with flavonoids content with $r=-0,78$. From these result, we can deduced that total phenolic coumponds are more effectif than flavonoids in this activity. The presence of the reductants in the solution causes the resuction of the $\mathrm{Fe}$ ${ }^{+3}$ to the $\mathrm{Fe}^{+2}$. Various reports suggested that the reducing properties have been shown to exert antioxydant action by donating of a hydrogen atom to break the free radical chain (Naima et al 2012).

Finally, a good correlation was abtained between the total antioxydant assay and total phenols $(r=0,98)$, also with flavonoids content $(\mathrm{r}=0,97)$. The phosphomolybdenum assay is based on the reduction of $\mathrm{Mo}(\mathrm{VI})$ to $\mathrm{Mo}(\mathrm{V})$ by the antioxydants and the subsequent formation of green phosphate/Mo(V) compounds (Naima et al 2012). According to Kasangana et al , (2015), polyphenols contained in the extract act by donating electrons and reacting with free radicals to convert them into more stable products and terminate free radical chain reaction.

As explained before the relationship between polyphenols, flavonoids content and the antioxydant activities was confirmed. We noted that with DPPH, and FRAP assays the correlation was negative, that can be explained by using value IC50 in analysis, because extract that have a lower IC50 value has good antioxydants properties. Our results consitent with the reports of Rosa et al 2006, and Kasangana et al 2015.

However, a positive correlation was obtained with phosphomolybdenum essay (total antioxydant assay), knowing that, The values of different coefficients are situated in the range of 0,6 and 1 ; indicating a very strong relationship and correlation between the amount of polyphenols content in extracts and differents antioxydants activities.

Our results are according to many other resarch studies which confirm this correlation between polyphenols, flavonoids content and antioxydants activities Kasangana et al (2015); Zhang et al (2013); Kopjar et al (2009); Tawaha et al (2007); Katalinic et al (2006); Cai et al (2004); Zheng \& Wang (2001); Kalt et al (1999).

\section{Conclusion}

Cleome Arabica ssp arabica is wide spread and well-known species of the Algerian desert. Despite its importance in local traditional medicine and its abundance in the region, it remains under economically not heavily exploited. The present study focused on the antioxidant properties of Cleome Arabica.

It is a safe and effective intervention for free radical mediated diseases. The results obtained in this study suggested that $C$. arabica leaf's 
extract proved superior efficacy significant differences over the three methods evaluation of antioxidant activity.

The high contents of phenolic compounds and significant linear correlation between the values of the concentration of phenolic compounds and antioxidant activity indicated that these compounds contribute to the strong antioxidant activity of Cleome Arabica.

\section{Acknowledgement}

I would like to thank Mr Tabet Slimane for his assistance and help.

\section{References:}

1. Ahmad, I., Malik, M.I., Iqbal, K., Ahmad, K., \& Naz, S. (1990). Efficacy of formalinized liver organ vaccine against Angara disease in broilers. Veterinary Arhiv, 60, 131-8.

2. Amarowicz, R., Estrella, I., Hernández, T., Robredo, S., Troszynska, A., Kosinska, A., \& Pegg, R.B. (2010). Free radical scavenging capacity, antioxydant activity, and phenolic composition of green lentil (lens culinaris). Food Chemistry, 121, 705 -711.

3. Amzad, H.M., AL-Raqmi, K.A., AL-Mijizy, H.Z., Weli, M.A., \& AlRiyami, Q. (2013). Study of total phenol, flavonoids contents and phytochemical screening of various leaves crude extracts of locally grown Thymus vulgaris. Asian pacific journal of tropical biomedicine, 9, 705-710.

4. Aruoma, O.I., Spencer, J.P., Butler, J., \& Halliwell, B. (1995). Reaction of plant-derived and synthetic antioxidants with trichloromethylperoxyl radicals. Free Radical Reseach, 22(2),187-90.

5. Baba Aissa, F. (2011). Encyclopédie des plantes utiles. El maarifa (Ed) Alger, 471.

6. Boulos, L. (1983). Medicinal Plants of North Africa. Reference Publication Inc Michigan USA ; 52.

7. Bouriche, H., \& Arnhold, J. (2010). Effect of Cleome arabica leaf extract treated by naringinase on neutrophil degranulation. Acta Horticulturae, 854, 15-22.

8. Braho, Z.L., Olgica, D.S., Sava, M. V., Ivana, D.R., Milan, S.D., \& Ljiljana, R.C. (2013). Biological activities of the extracts from wild growing Origanum vulgare L. Food control, 33, 498-504.

9. Cai, Y., Luo, Q., Sun, M., \& Corke, H. (2004). Antioxidant activity and phenolic compounds of 112 traditional Chinese medicinal plants associated with anticancer. Life Science, 74, 2157-2184.

10. Carocho, M., \& Ferreira, I.C. (2013). A review on antioxidants, prooxidants and related controversy: natural and synthetic 
compounds, screening and analysis methodologies and future perspectives. Food Chemical Toxicology Journal , 51, 15-25.

11. Cascon, S.C., \& Brown, K.S. (1972). Biogenetically Significant Triterpenes in a Species of Meliaceae: Cabralea Polytricha A. Juss Tetrahedron, 28, 315-323.

12. Das, N.P., \& Pereira, T.A. (1990). Effects of favonoids on thermal autoxidation of palm oil structure-activity relationships. Journal of the American Oil Chemists' Society ,67, 255- 258.

13. Dawood, M.S., \& Amzad, H.M. (2011). Total flavonoids content and biochemical screening of the leaves of tropical endemic medicinal plant Merremia borneensis. Arabian journal of chemistry.

14. Diouf, P., Stevanovic, T., \& Cloutier, A. (2009). Antioxidant and polyphenol contents of trembling aspen bark extracts. Wood Science and Technology, 43, 457-470.

15. Djeridane, A., Yousfi, M., Brunel, J.M., \& Stocker, P. (2010). isolation and characterisation of new steroid derivative as a powerful antioxydant from Cleome arabica in screening the in vitro antioxydant capacity of 18 Algerian medicinal plants. Food and chemical toxicology, 48, 2599-2606.

16. Djeridane, A., Yousfi, M., Nadjemi, B., Boutassouna, D., Stocker, P., \& Vidal, N. (2006). Antioxidant activity of some algerian medicinal plants extracts containing phenolic compounds. Food chemistry, 97, 654-660.

17. Einbond, L.S., Reynertson, K.A., Luo, X.D., Basile, M.J., \& Kennelly, E.J. (2004). Anthocyanin antioxidants from edible fruits. Food Chemistry, 84, 23-28.

18. El-Mougy, S., Abdel-Aziz, S., Al-Shanawany, M., Omar, A. (1991). The gonadotropic activity of Palmae in mature male rats. Journal of Pharmaceutical Science, 5, 156-159.

19. Foti, M., Piatelli, M., Baratta, M.T., \& Ruberto, G. (1996). Flavonoids, coumarins, and cinnamic acids as antioxidants in a micellar system. Structure-activity relationship. Journal Agriculture and Food Chemistry, 44, 497-501.

20. Harbone, J.B. (1998). Phytochemical methods : a guide to modern techniques. $2^{\text {nd }}$ Edition, London, Chapman and hall, $54-84$.

21. Harraz, F.M., Ulubelen, A., Öksüz, S., \& Tan N. (1995). Dammarane triterpenes from Cleome amblyocarpa. Plant chemistry, 39 (1), 175178.

22. Ismail, S.I., Ito, H., Selloum, L., Bouriche, H., Yoshida, T. (2005). Constituents of Cleome arabica leaves and twigs. Natural Medicines, $59,53$. 
23. Jente, R., Jakupovic, J., \& Olatunji, G.A. (1990). A Cembranoid diterpene from Cleome viscosa. Phytochemistry, 29, 666-667.

24. Kalt, W., Forney, C.F., Martin, A., \& Prior, R.L. (1999). Antioxidant capacity, vitamin $\mathrm{C}$, phenolics, and anthocyanins after fresh storage of small fruits. Journal of Agricultural and Food Chemistry, 47, 4638-4644.

25. Karabegovic, I., Nikolova, M., Velickovic, D., Stojicevic, S., Veljkovic, V., \& Lazic, M. (2011). Comparaison of antioxydant and antimicrobial activities of methanolic extracts of the Artemisia sp. Recovered by different extraction techniques. Chinese Journal of Chemical Engineering ,19, $504-511$.

26. Kasangana, P.B., Haddad, P.S., \& Stevanovic, T. (2015). Study of polyphenol content and antioxydant capacity of Myrianthus Arboreus (Cecropiaceae) root bark extract . Antioxydant, 4, 410-426.

27. Katalinic, V., Milos, M., Kulisic, T., \& Jukic, M. (2006). Screening of 70 medicinal plant extracts for antioxidant capacity and total phenols. Food Chemistry, 94, 550-557.

28. kopjar, M., Pilizota, V., Hribar, J., \& Simcic, M. (2009). Total phenol content and antioxydant activity of water solution of plant extracts. Croatian Journal of Food Science and Technology, 1, 1-7.

29. Krishnaiah, D., Rosalam, S., \& Rajesh, N. (2011). A review of the antioxidant potential of medicinal plant species. Food and Bioproducts Processing, 89, 217-233.

30. Ladhari, A., Laarif, A., Omezzine, F., Haouala, R. (2013). Effect of the extracts of the spiderflower, Cleome arabica, on feeding and survival of larvae of the cotton leafworm, Spodoptera littoralis. Journal of Insect Science, 13: 61.

31. Laghari, A.Q., Memon, S., Nelofar, A., \& Laghari, A.H. (2013). Tecomella undulata G. Don: a rich source of flavonoids. Industrial crop and products, 43, 213- 217.

32. Naima, S., Khan, R.M., \& Shabbir, M. (2012). Antioxydant activity, total phenolic and total flavonoid contents of whole plant extracts Torilis leptophylla L. BMC complementary and alternative madicine, 12, 221.

33. Nieto, S., Garrido, A., Sanhueza, J., Loyola, L.A., Morales, G., Leighton, F., Valenzuela, A. (1993). Flavonoids as stabilizers of fish oil, an alternative to synthetic antioxidants. Journal of the American Oil Chemists' Society, 70, 773 -778.

34. Oomah, B.D., \& Mazza, G. (1996). Flavonoids and antioxidative activities in buck-wheat. Journal of Agricultural and Food Chemistry, 44, 1746-1750. 
35. Perron, N.R., \& Brumaghim, J.L. (2009). A Review of the Antioxidant Mechanisms of Polyphenol Compounds Related to Iron Binding. Cell Biochem Biophys, 53, 75-100.

36. Rizk, A.M. (1982) Constituents of plants growing in Qatar. Fitoterrapia, 35- 42.

37. Rosa, R.M., Melecchi, M.I., Halmenschlager, R.D.C., Abad, F.C., Simoni, C., Caramao, E.B., Henriques, J.A., Saffi, J., \& de Paula Ramos, A.L. (2006). Antioxidant and antimutagenic properties of Hibiscus tiliaceus methanolic extract. Journal of Agriculture and Food Chemitry, 54, 7324-7330.

38. Seigler, D.V. (2002). Plant Secondary Metabolism. Kluwer Academic Publisher, $2^{\text {nd }}$ edition.

39. Selloum, L., Sebihi, L., Mekhalfia, A., Mahdadi, R., \& Senator, A. (1997). Antioxidant activity of Cleome arabica leaves extract. Biochemical Society Transactions, 25, 608.

40. Sharaf, M., El-Ansari, M.E., \& Saleh, N.A.M. (1997). Flavonoids of four Cleome and three Capparis species. Biochemical Systematics and Ecology, 25, 161-166.

41. Schwartsburd, P.M. (2003). Chronic inflammation as inductor of procancer microenvironment: Pathogenesis of dysregulated feedback control. Cancer and Metastasis Reviews, 22, 95-102.

42. Siddhuraju, P., Mohan, P.S., \& Becker, K. (2002). Studies on the antioxidant activity of Indian Laburnum (Cassia fistula L.): a preliminary assessment of crude extracts from stem bark, leaves, flowers and fruit pulp. Food Chemitry,79, 61-67.

43. Soares, S. E. (2002). Ácidos fenólicos como antioxidantes. Revista de Nutrição, 15, 71-81.

44. Stevanovic, T., Diouf, P.N., \& Garcia-Perez, M.E. (2009). Bioactive Polyphenols from Healthy Diets and Forest Biomass. Current Nutrition \& Food Science, 5, 264-295.

45. Sudha, G., Sangeetha, M.P., Indhu, R.S., Vadivukkarasi, S. (2011). invitro free radical scavenging activity of raw Pepino fruit (Solanum muricatum). International journal of current pharmaceutical research, 3, 137-140.

46. Takhi, D., Ouinten, M., \& Yousfi, M. (2011). Study of Antimicrobial Activity of Secondary Metabolites Extracted Fromspontaneous Plants from the Area of Laghouat, Algeria. Advances in Environmental Biology, 5(2), 469-476.

47. Tawaha, K., Alali, F,Q., Gharaibeh, M., Mohammad, M., \& ElElimat, T. (2007). Antioxidant activity and total phenolic content of selected Jordanian plant species ; Food Chemistry, 104,1372-1378. 
48. Tigrine, C., Bulzomi, P., Leone, S., Bouriche, H., Kameli, A., \& Marino, M. (2013). Cleome arabica leaf extract has anticancer properties in human cancer cells. Pharmaceutical Biology, 51, 150814.

49. Touil, A., \& Rhouati, S. (1998). Flavonol glycosides from Cleome arabica. Journal de la société algerienne de chimie, 8, 117-120.

50. Tsichritzis, F., Abdel-Mogip, M., \& Jakupovic, J. (1993). Dammarane triterpènes from Cleome africana. Phytochemistry, 33, 423-5.

51. Vermerris, W., \& Nicholson, R. (2008). Phenolic compound biochemistry. Springer, 7-15.

52. Zhang, D., Liu, Y., Le, C., Wei, Y., Wang, D., Cai, S., Zhou, F., \& Ji, B. (2013). Relationship between the structures of flavonoids and oxygen radical absorbance capacity values. A quantum chemical analysis. Journal Physical Chemistry, 117, 1784-1794.

53. Zheng, W., \& Wang, S.Y. (2001). Antioxidant activity and phenolic compounds in selected herbs. Journal of Agricultural and Food Chemistry, 49, 5165-5170. 